\title{
OrganisaATIOKANSAlaisuUs KOROSTUU TYÖYHTEISÖJEN MUUTOKSISSA ${ }^{1}$
}

Marjut Arola: YTT, yliopettaja, Karelia-ammattikorkeakoulu

marjut.arola@karelia.fi

Janus vol. 29 (1) 2021, 71-76

\begin{abstract}
Mun mielestä lintutorni kuvaa selkeästi organisaatiota. Tommonen lintutorni, joka erottuu maastosta. Se on ilmeisen selvä jut$t u$, missä pomot tuossa tornissa on. Mun mielestä niiden pitää olla korkeimmalla kohtaa, just sen takia, et ne näkee mihin mennään. Ja että ne osaa vaihtaa vaihteita sieltä ylhäaltä, ja suunnata tota tornia johonkin suuntaan. Alemmissa kerroksissa on sitten työntekijöitä sen mukaan, mihin ollaan menossa. Hyvässä organisaatiossa työt voi olla hyvinkin eriytyneitä, mutta välillä joudutaan myös tekemään yhteistyötä aika tiiviisti. Lintutorni on aika mainio, koska siinä joutuu yhteistyöhön myös sen yläkerran kanssa.
\end{abstract}

Haastateltava sosiaalityöntekijä jatkaa kuvaamalla kokemuksiaan johtamisesta ja työn kehittämisen ongelmista:

Mut sitten, jos lintutornissa ei ole minkäänlaista johtoa eikä kukaan sano, että mihin päin mennään. On vaan paljon erilaisia juttuja, joista sovitaan, että tehdään näin, mutta kukaan ei muista niitä enää kuukauden päästä. Siitä seuraa se, että jos ollaan sovittu, että tänä vuonna panostetaan tällaiseen asiaan, niin sitten huomataankin, että eihän me olla tällaista asiaa muistettukaan. Vaikka sovittiin, että kehitetään, niin eipä ollakaan tehty mitään! Tämä on kauhean tyypillistä sosiaali- ja terveydenhuollossa tai ainakin niissä työpaikoissa, joissa minä olen ollut töissä.

\begin{abstract}
Paras juttu mun ammattihistorian aikana oli se, kun ylilääkäri pyysi meidät keskusteluun ja sanoi, että kuulkaas pojat, nyt tarvittais sellaista miesten lyömätön -ryhmää, olisitteko kiinnostuneita? Se oli siihen aikaan kova aihe. No, me vastattiin, että joo joo! Sit me keskusteltiin siitä, että tämä on tosi hyvä juttu ja meidän kannattaa perustaa tällainen ryhmä. Kun me sitten Matin kanssa lähdettiin pois siitä palaverista, niin sovittiin heti huoneen ulkopuolella, että tästä aiheesta ei sitten kuuna päivänä keskustella enää. Eikä sitä ryhmää koskaan tullut! Kukaan ei myöskään koskaan kysynyt siitä, koska me tiedettiin jo heti kättelyssä, että tää on taas niitä juttuja, jotka hautautuu. Me ei oltu oikeasti kiinnostuneita siitä, eikä ollut johtokaan. Mun mielestä organisaatioiden ongelma on se, että ei saada työntekijöitä oikeasti mukaan ja sitoutumaan niihin kehittämisjuttuihin. Ja silloinhan mikään ei liikahda minnekään.
\end{abstract}

Näin pitkän työuran tehnyt sosiaalityöntekijä kuvasi ryhmähaastattelussa ajatuksiaan organisaatiokansalaisuudesta. Tarinassa on tuttuja elementtejä kaikille sosiaali- ja terveydenhuollon työntekijöille ja siihen on helppo samaistua. Se kertoo organisaatioiden toiminnasta, mutta ennen kaikkea työntekijöistä organisaatioiden jäseninä. Vaikka tarinassa kuvataan ensisijaisesti sosiaali- ja terveydenhuollon julkisten organisaatioiden toimintaa, on se helposti yleistettävissä muidenkin toimialojen 
organisaatioihin. Tarinasta välittyy sosiaalityöntekijän kokemuksia yhteistyöstä, luottamuksesta, sitoutumisesta ja johtamisesta organisaatioissa.

Tutkin väitöstutkimuksessani (Arola 2020) organisaatiokansalaisuutta sosiaalityön professiossa. Tutkimustehtävänä oli selvittää, millaisia odotuksia, vaatimuksia ja jännitteitä sosiaalityön professioon kohdistuu organisaatiokansalaisuudessa sosiaali- ja terveydenhuollon moniammatillisissa ja uudistuvissa työyhteisöissä. Tutkimukseni tavoitteena oli tuottaa tietoa sosiaalityön organisaatiokansalaisuudesta, jota on tutkittu kansainvälisestikin vielä verrattain vähän. Menetelmällisenä tavoitteena oli täydentää vahvasti määrälliseen tutkimusperinteeseen perustuvaa organisaatiokansalaisuustutkimusta sekä tuottaa tietoa laadullisten menetelmien käytettävyydestä.

Tutkimukseni muodostuu kolmesta osatutkimuksesta ja niiden yhteenvedosta. Ensimmäisessä osatutkimuksessa (Arola ym. 2020a) tutkimme sosiaali- ja terveysalan korkeakouluopiskelijoiden ammatillisen toimijuuden rakentumista koulutuksen aikana. Tutkimusaineistona olivat sosiaali- ja terveysalan kansainvälisiltä opiskelijoilta eläytymismenetelmällä kerätyt tarinat, jotka analysoin kehysanalyysilla. Tutkimusartikkeli on julkaistu Yliopistopedagogiikka-lehden numerossa 1/2020.

Toisessa osatutkimuksessa (Arola ym. 2018) selvitimme sitä, millaisista piirteistä organisaatiokansalaisuus rakentuu sosiaali- ja terveysalalla. Empiirisenä aineistona oli sosiaali- ja terveydenhuollossa työskennelleiltä YAMK-opiskelijoilta eläytymismenetelmällä kerätyt tarinat, jotka analysoin teoriasidonnaisella sisällönanalyysilla. Tutkimusartikkeli on julkaistu Työelämän tutkimus -lehdessä.

Kolmannessa osatutkimuksessa (Arola ym. 2020b) tutkimme aineistolähtöisesti sitä, millaista ongelmapuhetta sosiaalityöntekijät tuottavat organisaatiokansalaisina. Empiirisenä aineistona oli kolme sosiaalityöntekijöiden fokusryhmähaastattelua, joissa hyödynsin osallistavan valokuvauksen menetelmää. Ryhmähaastatteluaineiston analysoin teoriasidonnaisella sisällönanalyysilla. Tutkimusartikkeli julkaistiin Focus Localis -lehden numerossa 1/2020.

Tutkimukseni tulokset osoittavat, että organisaatiokansalaisuus laajentaa sosiaalityön ammatillisen osaamisen kokonaisuutta, jota on perinteisesti jäsennetty ammattikohtaisten ja asiakastyöhön kiinnittyvien professionaalisuustarkastelujen kautta. Organisaatiokansalaisuus täydentää sosiaalityön ammatillisuutta työyhteisöjen muutoksiin kiinnittyvällä organisaatio- ja työyhteisöosaamisella, jolloin painopiste siirtyy yksilöllisen asiantuntijuuden tarkastelusta kohti monitoimijaista ja yhteisöllisessä toiminnassa rakentuvaa osaamista. Organisaatiokansalaisuustaitojen merkitys korostuu erityisesti sosiaali- ja terveydenhuollon palvelurakenteiden ja työtapojen muutoksissa.

Organisaatiokansalaisuus on käsitteenä moniulotteinen ja suomeksi jopa vaikeastikin määriteltävä. Suomalaisessa organisaatiokirjallisuudessa se on rinnastettu esimerkiksi työyhteisökyvyn (esim. Mattila 2013), alaistaitojen (esim. Keskinen 2005), työyhteisötaitojen (esim. Karhapää ym. 2015; Roos 
\& Mönkkönen 2015) tai ammatillisen toimijuuden käsitteisiin (esim. Littleton ym. 2012). Organisaatiokansalaisuudella tarkoitetaan työntekijän ja organisaation jäsenen ammatillisen roolin ylittäviä persoonallisuuden ja käyttäytymisen piirteitä,joita pidetään yleisesti sopivina tai tavoiteltavina, mutta joita häneltä ei työroolissa voida virallisesti vaatia. Tällaisina hyveellisinä työntekijyyden piirteinä on perinteisesti pidetty esimerkiksi auttamista, tunnollisuutta, reiluutta, huomaavaisuutta ja lojaalisuutta. (Organ 1988; Podsakoff ym. 2000.)

Nykyinen organisaatiokansalaisuuskeskustelu kiinnittyy vahvasti organisaatioiden muutokseen ja tietointensiiviseen työhön (esim. Dekas ym. 2014; Laulainen 2010; Sadegh 2015; Simo ym. 2016). Toimintaympäristöjen muutoksissa työntekijöiltä vaaditaan yhä enemmän sellaisia ominaisuuksia, jotka edistävät organisaatioiden uudistumista ja parantavat niiden kilpailuasetelmia. Tällöin ihanteellisen työntekijän ominaisuuksina korostuvat esimerkiksi muutosmyönteisyys, itseohjautuvuus, innovatiivisuus, määrätietoisuus ja uuden tiedon tuottaminen.

Sosiaali- ja terveydenhuollossa, ja etenkin sosiaalityössä organisaatiokansalaisuudesta puhutaan vielä varsin vähän, vaikka sitä on kansainvälisesti tutkittu jo yli 30 vuoden ajan. Organisaatiokansalaisuutta on tutkittu eniten liiketalousja johtamistieteissä, ja erityisesti palvelualojen työssä.Tutkimus on lisäntynyt merkittävästi 2000-luvulta alkaen, koska organisaatiokansalaisuudella on todettu olevan myönteisï vaikutuksia organisaatioiden tuottavuuteen, palveluiden laatuun, työyhteisöjen toimin- taan ja työntekijöiden työhyvinvointiin (Jain 2012; Mashi 2018; Ocampo ym. 2018). Näistä syistä kiinnostus organisaatiokansalaisuuden vahvistamiseen on lisääntynyt myös julkisella sektorilla ja sosiaali- ja terveydenhuollossa.

Työelämän ja organisaatioiden muutokset edellyttävät työntekijöiltä uudenlaista osaamista. Sosiaali- ja terveydenhuollossa tarvitaan tulevaisuudessa vahvan ammattialakohtaisen substanssiosaamisen lisäksi esimerkiksi jaettua sote-osaamista, integroivaa osaamista, rajatyöosaamista ja työntekijyysosaamista (Kangasniemi ym. 2018). Tulevaisuuden sote-osaamisessa korostuvat siten entistä vahvemmin yhteisölliseen osaamiseen ja organisaatiokansalaisuuteen liittyvät taidot. Myös sosiaalityöntekijöiltä odotetaan perinteisen asiakastyön osaamisen lisäksi yhteistyö- ja kehittämisvalmiuksia, moniammatillisuusosaamista sekä palveluiden kilpailuttamiseen, tuotteistamiseen ja vaikuttavuuden arviointiin liittyvää liiketoimintaosaamista.

Sosiaalityön ammatilliseen osaamiseen ja sosiaalityöntekijöiden toimintaan kohdistuvat odotukset ja muutospaineet voivat olla ristiriitaisia ja yksittäisen työntekijän näkökulmasta jopa mahdottomiakin täyttää. Sosiaalityöntekijät kokevatkin, että työn jatkuvat muutokset, työmärän lisääntyminen ja työn tehostamisvaatimukset ovat lisänneet työn kuormittavuutta ja heikentäneet työntekijöiden työhyvinvointia varsinkin, kun samanaikaisesti sosiaalityön asiakasmäärät ovat kasvaneet ja asiakkaiden sosiaaliset ongelmat monimuotoistuneet. 
Ristiriitaiset odotukset ovat lisänneet sosiaalityöntekijöiden kokemaa kansalaisuusuupumusta. Se ilmenee esimerkiksi turhautumisena ja väsymisenä organisaation jatkuviin muutos- ja kehittämisprosesseihin, ulkoapäin tuleviin työn tehostamisvaatimuksiin ja kaventuneisiin mahdollisuuksiin tehdä asiakaslähtöistä ja ammattieettisesti kestävää sosiaalityötä. Sosiaalityöntekijät kokevat myös, että heidän mahdollisuutensa kehittää omaa työtään ja sosiaalityön palveluita ovat rajallisia, eikä sosiaalityön asiantuntijuutta ja osaamispotentiaalia hyödynnetä riittävästi muutosten toteuttamisessa. (Arola ym. 2020b.) Sosiaalityöntekijöiden kansalaisuusuupumus voi näkyä työyhteisöissä passiivisuutena ja muutosvastarintana, jopa kehittämistoiminnasta kieltäytymisenä. Kansalaisuusuupumuksen kokemukset voivat heikentää työntekijöiden organisaatioita kohtaan kokemaa luot- tamusta ja työhön sitoutumista, jotka puolestaan ennustavat sosiaalityölle ominaista työntekijävaihtuvuutta ja ääritapauksissa jopa ammatin vaihtoa.

Sosiaalityöntekijöiden organisaatiokansalaisuustaitojen vahvistamiseen tulee kiinnittää huomiota koulutuksessa, ammatillisessa toiminnassa ja työorganisaatioissa (kuvio 1). Koulutuksessa opiskelijalle tulee luoda edellytyksiä joustavan, moninaisen ja muuntautuvan ammattiidentiteetin ja organisaation jäsenyyden kehittymiselle. Ammatillisen toiminnan näkökulmasta työyhteisöissä on tärkeää vahvistaa sosiaalityöntekijöiden kehittämis- ja muutosvalmiuksia sekä työhyvinvointi- ja yhteistyötaitoja. Työorganisaatioilta organisaatiokansalaisuuden vahvistaminen puolestaan edellyttää sosiaalityöntekijöiden ammatillisen autonomian ja muutososallisuuden mah-

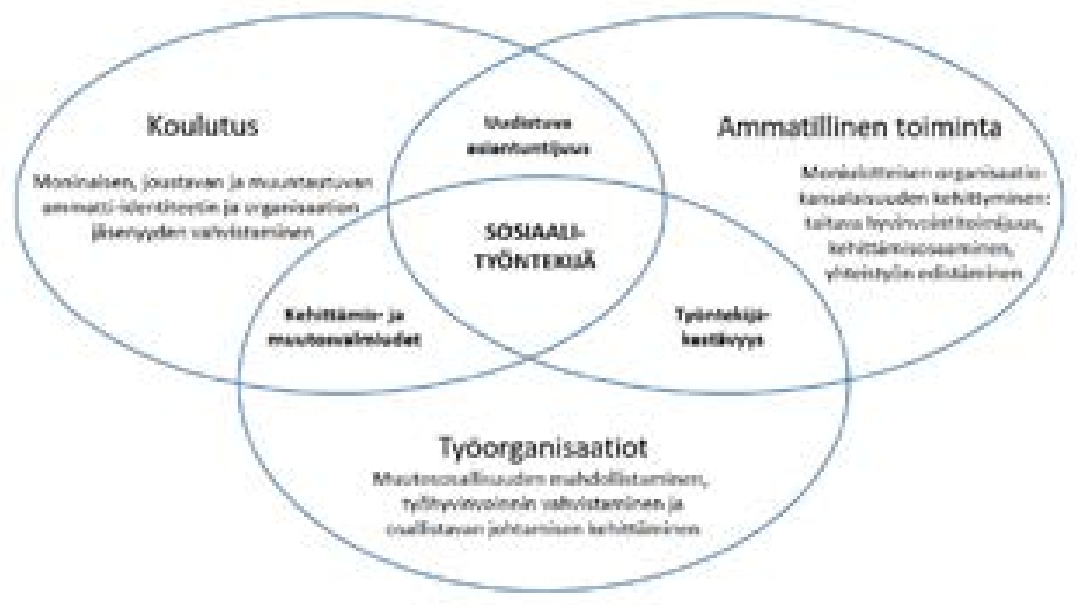

Kuvio 1. Organisaatiokansalaisuuden haasteet sosiaalityön professiolle. 
dollistamista sekä työhyvinvoinnin ja osallistavan johtamisen kehittämistä.

Sosiaalialan ammatillista osaamista ja asiantuntijuutta tarvitaan sosiaali- ja terveydenhuollon palveluiden monialaisessa kehittämisessä sekä sote-palveluiden tuloksellisuuden ja yhteiskunnallisen vaikuttavuuden vahvistamisessa. Sosiaalityölle voi avautua myös uusia tehtäviä moniammatillisessa ja organisaatioiden välisessä yhteistyössä. Se voi olla esimerkiksi avainasemassa työyhteisöjen osallisuuden ja yhteistyön edistäjänä sekä verkostojen koordinoijana.

Sosiaalityöntekijät ovat organisaatiokansalaisina omaa osaamistaan kehittäviä, aktiivisia ja muutosmyönteisiä, mutta myös kriittisiä muutostoimijoita. Sosiaalityön kriittiselle ja ammattieettisesti vastuulliselle osaamiselle onkin kysyntää organisaatioiden toiminnan kehittämisessä, koska rakentava kriittisyys ohjaa organisaatioiden toimijoita pohtimaan työnsä tavoitteita ja perusteita syvällisemmin. Sosiaalityöntekijöiltä hyvän organisaatiokansalaisuuden ja aktiivisen muutostoimijuuden haltuun ottaminen edellyttää professionaalisen osaamisen tietoista laajentamista sekä ammatillista rohkeutta.

\section{VIITE}

1 Puheenvuoro on Itä-Suomen yliopistossa 14.8.2020 tarkastetun sosiaalityön väitöskirjan lectio praecursoria.

\section{KirJallisuUs}

Arola, Marjut (2020) Organisaatiokansalaisuus sosiaalityön professiossa. Publica- tions of the University of Eastern Finland, dissertations in Social Sciences and Business Studies No 228. Kuopio: ItäSuomen yliopisto.

Arola, Marjut \& Laulainen, Sanna \& Pehkonen, Aini (2018) Sosiaali- ja terveydenhuollon työntekijöiden näkemyksiä organisaatiokansalaisuuden piirteistä. Työelämän tutkimus 16 (1), 19-34.

Arola, Marjut \& Pehkonen, Aini \& Laulainen, Sanna (2020a) Sosiaali- ja terveysalan korkeakouluopiskelijoiden ammatillisen toimijuuden ideaalit. Yliopistopedagogiikka 27 (1). https://lehti. yliopistopedagogiikka.fi/2020/02/25/ terveysala-toimijuuden-ideaalit/. Luettu 11.9.2020.

Arola, Marjut \& Pehkonen, Aini \& Laulainen, Sanna (2020b) Organisaatiokansalaisuus sosiaalityöntekijöiden ongelmapuheessa. Focus Localis 48 (1), 5-23.

Jain, Ajay K. (2012) Profile of an ideal organizational citizen. Organizational citizenship behavior, in-role behavior, managerial skills and emotional intelligence. Teoksessa R. K. Pradhan \& S. Nutankumar Thingujam. Emotional intelligence: Optimizing human performance at work. Germany: LAP Lambart publisher, 81-96.

Kangasniemi, Mari \& Hipp, Kirsi \& Häggman-Laitila, Arja \& Kallio, Hanna \& Karki, Suyen \& Kinnunen, Pirjo \& Pietilä, Anna-Maija \& Saarnio, Reetta \& Viinamäki, Leena \& Voutilainen, Ari \& Waldén, Anne (2018) Optimoitu soteammattilaisten koulutus- ja osaamisuudistus. Valtioneuvoston selvitys- ja tutkimustoiminnan julkaisusarja 39/2018. Valtioneuvoston kanslia. http://julkaisut.valtioneuvosto.fi/bitstream/ handle/10024/160883/39-2018-Optimoitu\%20sote-osaaminen.pdf. Luettu 10.9.2020.

Karhapää, Merja \& Laulainen, Sanna \& Kivinen, Tuula (2015) Työyhteisötaidot sosiaali- ja terveydenhuollossa. Hallinnon tutkimus 34 (2), 162-172.

Keskinen, Soile (2005) Alaistaito: luottamus, sitoutuminen ja sopimus: Helsinki: Kunnallisalan kehittämissäätiö KAKS.

Littleton, Karen \& Taylor, Stephanie \& Eteläpelto,Anneli (2012) Special issue introduction: Creativity and creative work 
in contemporary working context.Vocations and Learning 5 (1), 1-4. https:// doi.org/10.1007/s12186-011-9067-4

Mashi, Munir S. (2018) The mediating role of job satisfaction in the relationship between organizational justice and employee outcomes. International Journal of Public Administration 41 (16), 13511360. https://doi.org/10.1080/0190069 2.2017.1388819

Mattila, Kari I. (2013) Työyhteisökyky: piilokustannus. Työpoliittinen aikakausikirja 56 (3), 44-47.

Ocampo, Landon \& Acedillo, Venus \& Bacunador, Alin M. \& Balo, Charity C. \& Lagdameo, Yvonne J. \& Tupa, Nickha S. (2018) A historical review of the development of organizational citizenship behavior (OCB) and its implications for the twenty-first century. Personnel Review 47 (4), 821-862. https://doi.
org/10.1108/PR-04-2017-0136

Organ, Dennis, W. (1988) Organizational citizenship behavior: The good soldier syndrome. Lexington: Lexington books.

Podsakoff, Philip M. \& McKenzie, Scott B. \& Paine, Julie B. \& Bachrach, Daniel G. (2000) Organizational citizenship behaviors: A critical review of the theoretical and empirical literature and suggestion for future research. Journal of Management 26 (3), 513-563. https://doi. org $/ 10.1177 / 014920630002600307$

Roos, Satu \& Mönkkönen, Kaarina (2015) Ihmisiksi työssä: työyhteisötaidoilla yhteistä vaikuttavuutta. Tallinna: UNIpress. Simo, Pep \& Sallan, Jose M. \& Fernandez, Vicenc \& Enache, Mihaela (2016) "Change-oriented organizational citizenship behavior:Analysis of antecedents centered on regulatory theory focus at the workplace". International Journal of Organizational Analysis 24 (2), 261-273. https://doi.org/10.1108/IJOA-102014-0805 